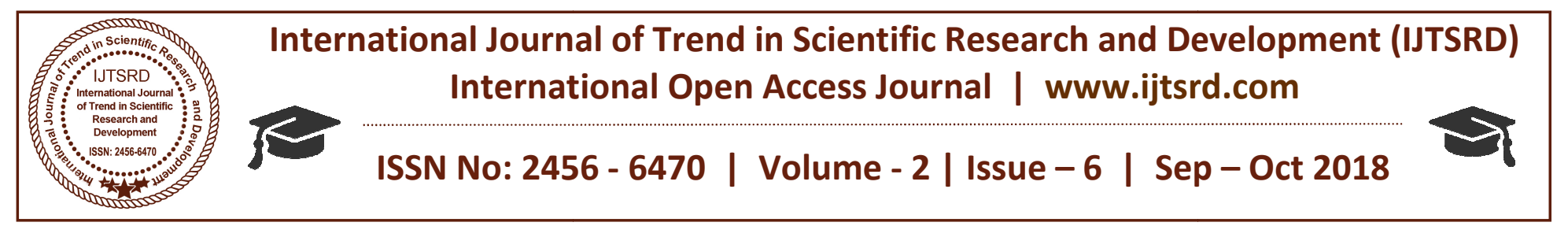

\title{
Effect of Quartz sand Grains Diameter on the Mechanical Properties of Mortars
}

\author{
Azhar Badaoui $^{1}$, Abdeslam Benamara ${ }^{2}$, Mohamed Amine Benaimeche ${ }^{2}$ \\ ${ }^{1}$ Professor, ${ }^{2}$ Master \\ Ecole Nationale Supérieure des Travaux Publics-Francis Jeanson- ENSTP-FJ \\ Sidi Garidi Kouba, Algiers, Algeria
}

\begin{abstract}
The aim of this study is to evaluate experimentally the influence of quartz (dune sand) incorporation in the cement matrix by mass substitution at different percentages and diameters, on the mechanical properties of the mortars.

Properties of the mortars were determined by flexural traction and compressive strength; the results obtained highlight the effect of the sand dune grain diameter on the mechanical properties of the mortars tested.
\end{abstract}

The use of quartz (dune sand) with a diameter of less than $0.16 \mathrm{~mm}$ improved the mechanical strength of mortars.

Keywords: quartz; sand grain; diameter; mortars component.

\section{INTRODUCTION}

Construction in civil engineering is generally carried out by prefabricated or cast-in-place elements which require a mortar without bleeding to ensure the connection.

A mortar is the hardened mixture of a binder (cement), a fine aggregate (sand) and water, according to its composition a mortar is none other than a finegrained concrete; it is therefore subject to the same laws as concrete. The largest granulates dimension D determines the name: mortar for $\mathrm{D} \leq 4 \mathrm{~mm}$, concrete for $\mathrm{D} \geq 4$ [1].

The incorporation of mineral additions such as quartz improved the mortar properties; these additions significantly affect the rheology of cementitious materials in the fresh state, which is directly related to the development of the strength and cured materials durability.

Quartz is a mineral species of the group of silicates; in the form of large colorless, colored or smoked crystals, or microscopic crystals of translucent appearance.

The quartz sand (dune sand) used in the mortar preparation, is fine golden sand with rolled grains $\left(D_{\max } \leq 0.63 \mathrm{~mm}\right)$, smooth surfaces, and a very small fineness.

Several researchers have studied the quartz effect addition on the properties of the cementitious material in the fresh and hardened state:

Granular effect, also called filler effect; relates to all modifications induced by the mineral additions presents in the cementitious material at the fresh state. These modifications may result from the stacking capacity of the fine or ultra-fine particles with the other solid components of the mixture and / or the intensity of the friction between the various particles of the mixture [2].

Physicochemical and micro structural effects are the modifications caused by the multiple interactions between the mineral addition particles on the cement hydration process and the structuring of the hydrated products [3].

Chemical effect or pozzolanic is the capacity of the additions to react with the water and the anhydrous or hydrated cement constituents to form new mineral phases which can contribute to the mechanical 
resistances evolution. Even for quartz (considered as inert in a cementitious medium), very fine crystallized quartz particles with a diameter of less than $5 \mu \mathrm{m}$ can also react with portlandite[4].

Adding of fine quartz particles improved the mechanical properties and durability of the concrete and a reduced the heat of hydration released from concrete, which decreases thermal cracking [3].

Cement production is a major consumer of energy, replacing it with mineral additions reduces the price of concrete and decrease the $\mathrm{CO}_{2}$ emission by the cement industry [1].

Mortars are present in all construction sectors and public works. Over the past 40 years, mortars have become increasingly complex; today, they combine hydraulic binders and multiple additives. Plaster mortars, tiling adhesives and repair mortars represent in terms of sales and quantities produced, the most important applications of all the mortars used. Their durability and strength is intimately related to the properties of its components.

This paper reports on the study the influence of the quartz grain diameter on the cement paste.

\section{Experimental procedures}

\section{A. Materials}

The Portland cement used in this study consisted of $95 \%$ of clinker and $5 \%$ of gypsum by weight. Table 1 summarises the chemical composition of clinker, gypsum and mineral admixtures.

\section{TABLE I. Chemical composition of cement}

\begin{tabular}{|c|c|c|c|c|c|c|c|c|c|}
\hline \multicolumn{1}{|l|}{ Element } \\
\hline $\mathrm{SiO}_{2}$ & $\mathrm{Al}_{2} \mathrm{O}_{3}$ & $\mathrm{Fe}_{2} \mathrm{O}_{3}$ & $\mathrm{CaO}$ & $\mathrm{MgO}$ & $\mathrm{SO}_{3}$ & $\mathrm{Na}_{2} \mathrm{O}$ & $\mathrm{CaO}$ & $\mathrm{K}_{2} \mathrm{O}$ & $\mathrm{Cl}^{-}$ \\
\hline 20,31 & 3,81 & 4,79 & 62,8 & 1.7 & 2,5 & 0,14 & 0,608 & 0,41 & 0,02 \\
\hline
\end{tabular}

The aggregates used were:

> Career sand with angular grains, a fineness modulus of 2.9 , apparent density of $1.59 \mathrm{~g} / \mathrm{cm}^{3}$, absolute density of $2.55 \mathrm{~g} / \mathrm{cm}^{3}$, spread granularity and maximum grain size of $5 \mathrm{~mm}$.

$>$ Quartz " dune sand " with rolled grains, a rounded shape and smooth surfaces, it has a fineness modulus of 0.8 , an apparent density of $1.46 \mathrm{~g} / \mathrm{cm}^{3}$, an absolute density of $2.50 \mathrm{~g} / \mathrm{cm}^{3}$, an tight granularity and maximum grain size of $0.63 \mathrm{~mm}$. Table 2 summarises the chemical composition of Quartz sand.

TABLE2. Chemical composition of quartz "dune sand"

\begin{tabular}{|c|c|c|c|c|c|c|c|c|c|}
\hline \multicolumn{2}{|l|}{ Element } \\
\hline $\mathrm{SiO}_{2}$ & $\mathrm{Al}_{2} \mathrm{O}_{3}$ & $\mathrm{Fe}_{2} \mathrm{O}_{3}$ & $\mathrm{CaO}$ & $\mathrm{MgO}$ & $\mathrm{SO}_{3}$ & $\mathrm{Na}_{2} \mathrm{O}$ & $\mathrm{CaO}$ & $\mathrm{K}_{2} \mathrm{O}$ & $\mathrm{Cl}^{-}$ \\
\hline 73,05 & 3,97 & 0,43 & 0,66 & 0,08 & 0,06 & 0,88 & --- & 2,15 & --- \\
\hline
\end{tabular}

For all mortar mixtures, the Sand to cement ratio and Water to cement ratio was kept constant at2, 0.5 by weight. The mix proportions of mortars are listed in Tables 3 , and 4.

TABLE 3.Mortars formulations

\begin{tabular}{|c|c|c|c|c|}
\hline \multicolumn{5}{|c|}{$0 \mathrm{~mm} \leq \mathrm{Dds} \leq 0.315 \mathrm{~mm}$} \\
\hline Sand mixture \% & Cement & Dune sand DS & Career sand CS & Water \\
\hline $100 \% \mathrm{DS}$ & $600 \mathrm{~g}$ & $1200 \mathrm{~g}$ & $/$ & $300 \mathrm{~g}$ \\
\hline $100 \% \mathrm{CS}$ & $600 \mathrm{~g}$ & $/$ & $1200 \mathrm{~g}$ & $300 \mathrm{~g}$ \\
\hline $\begin{array}{c}70 \% \mathrm{DS} \\
+30 \% \mathrm{CS}\end{array}$ & $600 \mathrm{~g}$ & $840 \mathrm{~g}$ & $360 \mathrm{~g}$ & $300 \mathrm{~g}$ \\
\hline $\begin{array}{c}70 \% \mathrm{CS} \\
+30 \% \mathrm{DS}\end{array}$ & $600 \mathrm{~g}$ & $360 \mathrm{~g}$ & $840 \mathrm{~g}$ & $300 \mathrm{~g}$ \\
\hline $\begin{array}{c}50 \% \mathrm{DS}+ \\
50 \% \mathrm{CS}\end{array}$ & $600 \mathrm{~g}$ & $600 \mathrm{~g}$ & $600 \mathrm{~g}$ & $300 \mathrm{~g}$ \\
\hline $100 \% \mathrm{DS}$ & 600 & $1200 \mathrm{~g}$ & $/$ & $300 \mathrm{~g}$ \\
\hline
\end{tabular}


TABLE 4. Mortars formulations

\begin{tabular}{|c|c|c|c|c|}
\hline \multicolumn{5}{|c}{$0.16 \mathrm{~mm} \leq \mathrm{Dds}<0.315 \mathrm{~mm}$ and Dds<0.16 mm } \\
\hline Sand mixture \% & Cement & Dune sand DS & Career sand CS & Water \\
\hline $100 \% \mathrm{CS}$ & $600 \mathrm{~g}$ & $/$ & $1200 \mathrm{~g}$ & $300 \mathrm{~g}$ \\
\hline $70 \% \mathrm{DS}+30 \% \mathrm{CS}$ & $600 \mathrm{~g}$ & $840 \mathrm{~g}$ & $360 \mathrm{~g}$ & $300 \mathrm{~g}$ \\
\hline $\begin{array}{c}70 \% \mathrm{CS} \\
+30 \% \mathrm{DS}\end{array}$ & $600 \mathrm{~g}$ & $360 \mathrm{~g}$ & $840 \mathrm{~g}$ & $300 \mathrm{~g}$ \\
\hline $\begin{array}{c}50 \% \mathrm{DS}+ \\
50 \% \mathrm{CS}\end{array}$ & $600 \mathrm{~g}$ & $600 \mathrm{~g}$ & $600 \mathrm{~g}$ & $300 \mathrm{~g}$ \\
\hline
\end{tabular}

Granulometric analysis was carried out on the sand mixtures used in the formulation of the mortars, as well as the determination of their fineness modulus.

The mixtures were cast into prismatic molds $(4 \mathrm{x} 4 \mathrm{x}$ 16) $\mathrm{cm}^{3}$, the moulds were stored in a moist reaction chamber(temperature of $20 \pm 2^{\circ} \mathrm{C}$ ); then, $24 \mathrm{~h}$ later, the moulds were removed and the specimens were stored in water until 24 hours before the rupture test.

\section{B. Mechanical properties}

A flexural traction strength tests were carried out on $\left(4 \mathrm{x} 4 \mathrm{x}\right.$ 16) $\mathrm{cm}^{3}$ prismatic specimens and a compressive strength tests were performed on pieces of prisms.

\section{Results and discussion}

Fig. 1 shows the granulometric curves of sand mixtures $(70 \% \mathrm{DS}+30 \% \mathrm{CS}, 50 \% \mathrm{DS}+50 \% \mathrm{CS}$, $30 \% \mathrm{DS}+70 \% \mathrm{CS}$ ) used in the mortar formulations; the granularity is well spread and continuous, with a fineness modulus of 1.6, 2, 2.4 respectively.

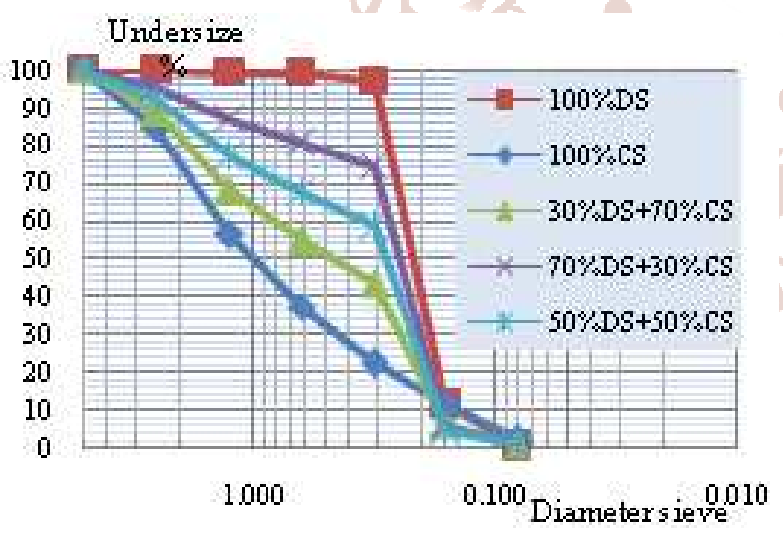

Fig. 1 Granulometric curves

\section{Compressive strength}

The relative compressive strengths of different specimens are plotted in Fig. 2, 3 and 4

For $0 \mathrm{~mm} \leq \mathrm{Dds} \leq 0.315 \mathrm{~mm}$;
As seen in Fig. 2, for a mortar blended with (30\% DS $+70 \% \mathrm{CS}),(50 \% \mathrm{DS}+50 \% \mathrm{CS})$, and $(70 \% \mathrm{DS}+$ $30 \% \mathrm{CS}$ ), the compressive strengths at 3 days were $23 \mathrm{MPa}, 23.3 \mathrm{MPa}$ and $21 \mathrm{MPa}$, respectively; they were 31.8 and $30.5 \mathrm{MPa}$ at 7 days.

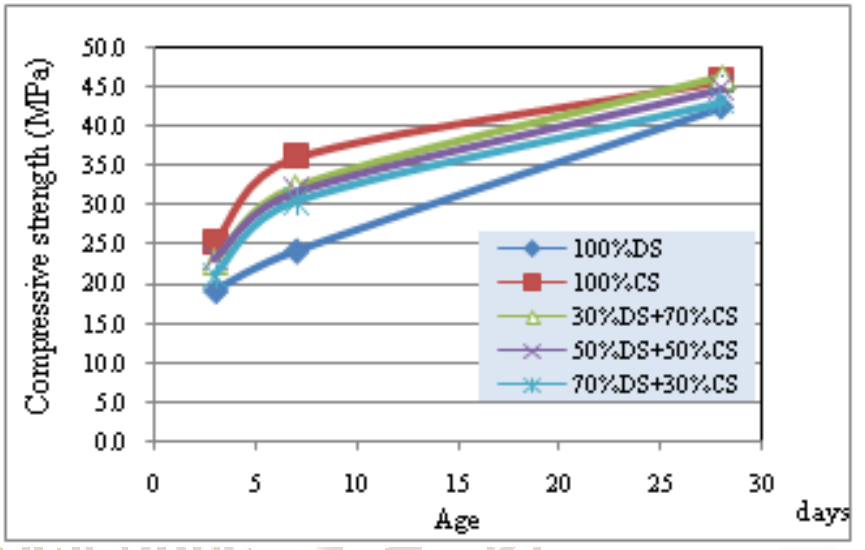

Fig. 2.Compressive strength for $0 \mathrm{~mm}$ $\leq \mathrm{Dds} \leq 0.315 \mathrm{~mm}$

The compressive strengths of these specimens were greater than those blended with «100\% DS» and were lower than that of «100\% CS » which has been confirmed by the previous studies [1].

At 28 days; mortars strengths increased by $9 \%, 5 \%$, $2 \%$ respectively. This was attributed to the densification of the microstructure caused by the spread granularity of sand mixtures and the fine quartz filler effect. In the literature, similar observations were also made by other researchers [7].

\section{For $0.16 \mathrm{~mm} \leq \mathrm{D}_{\mathrm{ds}}<0.315 \mathrm{~mm}$;}

All mortars developed the same compressive strengths for the same age (Fig. 3), it is due to the setting and similar hardening of these mortars, similar observations were also made by other researchers [7]; the curves of compressive strength highlight the influence of the total substitution of career sand by dune sand on the mechanical properties of the various mortars. 
International Journal of Trend in Scientific Research and Development (IJTSRD) ISSN: 2456-6470

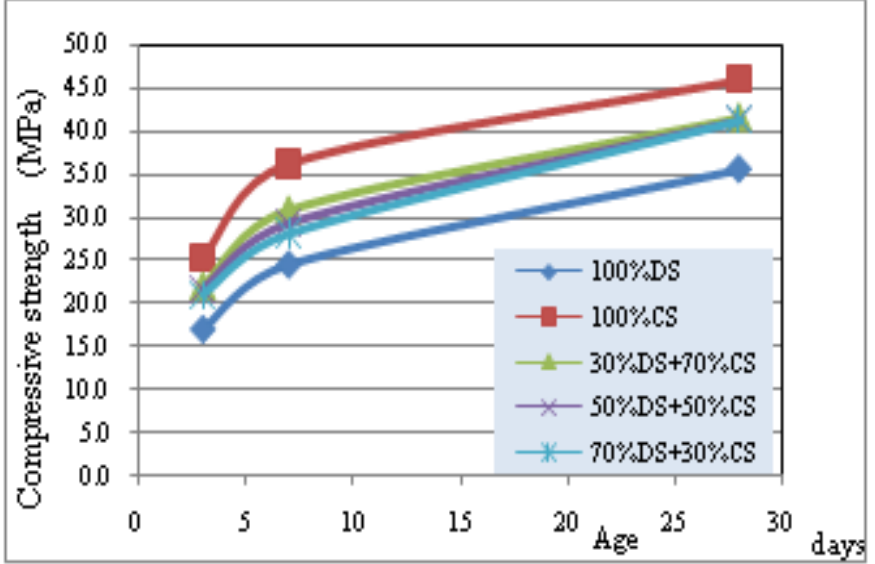

Fig; 3.Compressive strength for $0.16 \mathrm{~mm} \leq \mathrm{Dds}$ $\leq 0.315 \mathrm{~mm}$

$>$ For Dds $<0.16 \mathrm{~mm}$;

The compressive strength of the mortars blended with $(30 \% \mathrm{SD}+70 \% \mathrm{SC}),(50 \% \mathrm{SD}+50 \% \mathrm{SC})$, and $(70 \%$ $\mathrm{SD}+30 \% \mathrm{SC}$ ) increased on the order of $27 \%, 19 \%$, and $13 \%$, respectively compared to mortar (100\% SD) at 3 days, and $44 \%, 39 \%$, and $30 \%$ respectively at 7 days (Fig.4).

At 28 days; Compressive strength increased by $12 \%$, $10 \%$ and $2 \%$, respectively, and mortar blended with $(30 \% \mathrm{SD}+70 \% \mathrm{SC})$ had a better strength than the other mortars, The crystallized particles of dune sand are involved in the formation of the granular skeleton and contribute to the compactness of the cement matrix, which has been confirmed by the previous studies $[5,6]$.

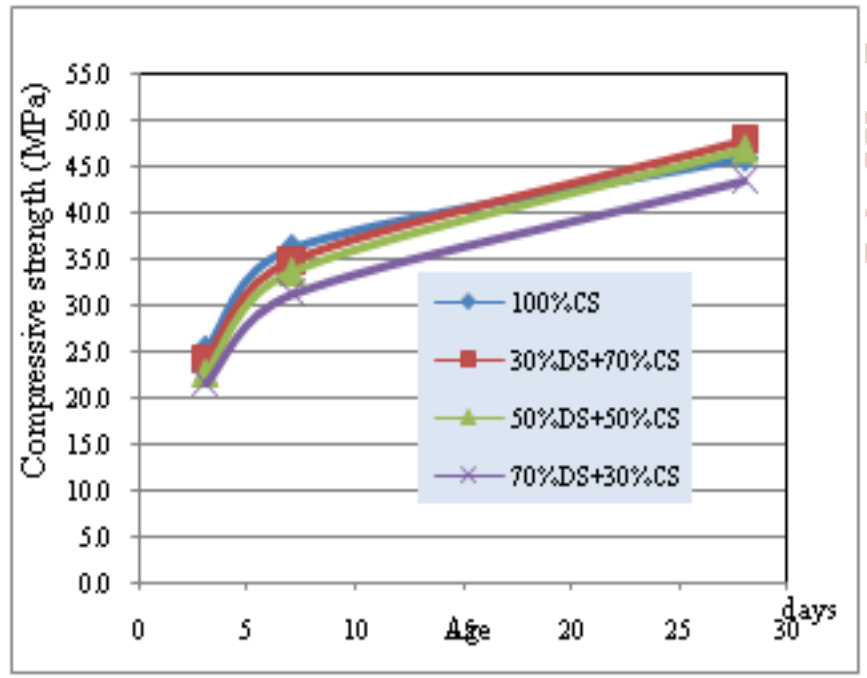

Fig.4. Compressive strength for $\mathrm{Dds}<0.16 \mathrm{~mm}$

\section{Flexural traction strength}

The relative flexural traction strength of different specimens is plotted in Figures 5, 6 and 7.

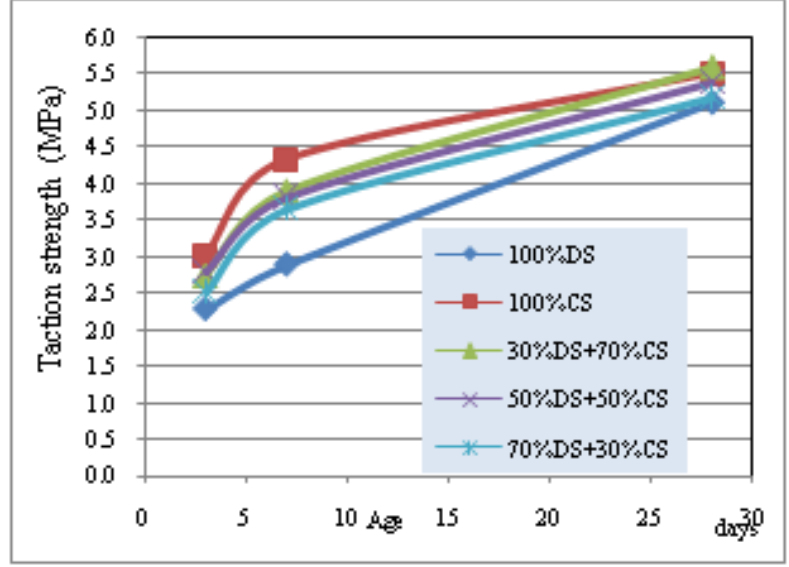

Fig.5. Traction strength for $0 \mathrm{~mm} \leq \mathrm{Dds} \leq 0.315 \mathrm{~mm}$

At the early stage (3 and 7 days), the flexural traction strengths of all specimens were almost similar and it substantially followed the compressive strength (Figure5).

At mature ages (28 days), the flexural traction strength of the mortars blended with the entire dune sand granular fraction $(0 \mathrm{~mm}<\mathrm{Dds} \leq 0.315 \mathrm{~mm})$ and the mortars blended with a fraction of sand dune $(0.16 \mathrm{~mm}<\mathrm{Dds}<0.315 \mathrm{~mm})$ were much lower than those blended with only Career sand. (Fig. 6 and 7).

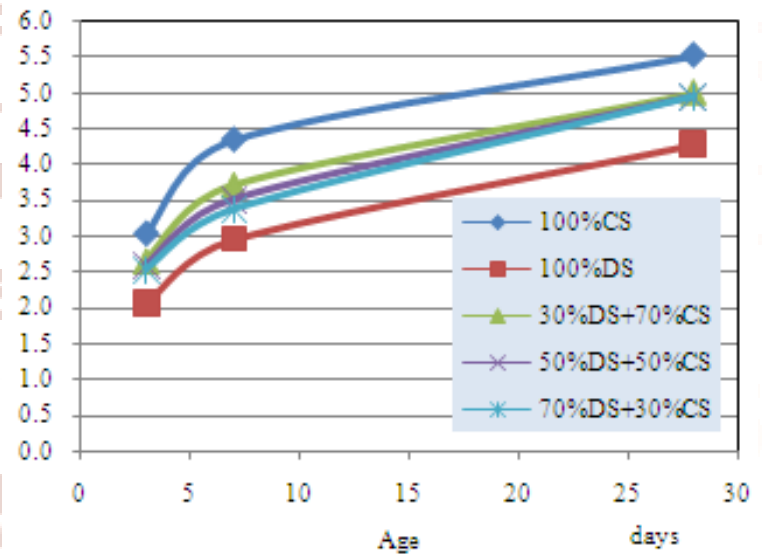

Fig.6. Traction strength for $0,16 \mathrm{~mm}$ $\leq$ Dds $<0.315 \mathrm{~mm}$

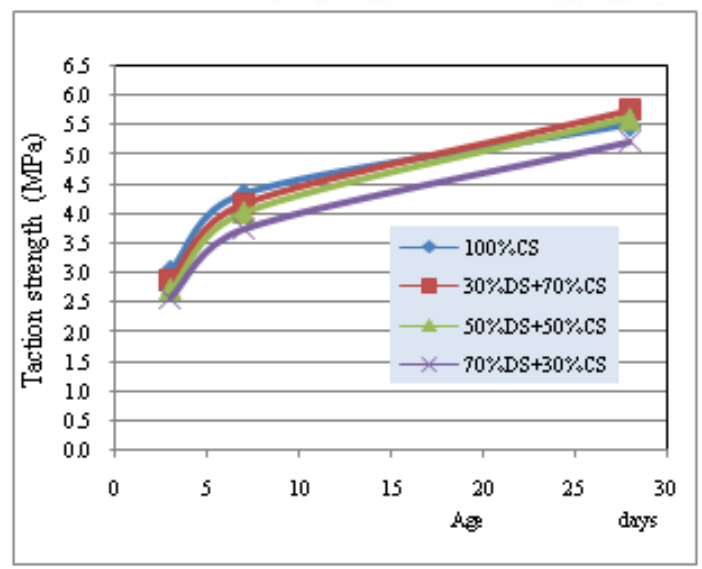

Fig.7. Traction strength for Dds $<0,16 \mathrm{~mm}$ 
Moreover, the flexural traction strength of the mortars blended with (30\% DS + 70\% CS) for Dds $<0.16 \mathrm{~mm}$, were greater than those blended with only Career sand.

So mortars (30\% SD + 70\% SC) containing a fraction of sand dune "D $<0.160 \mathrm{~mm}$ ", had the best mechanical characteristics for all ages including tensile strength.

\section{Conclusion}

The use of dune sand "quartz" in the preparation of mortars affect the mortars properties, the compressive strengths of all specimens blended with $(0 \mathrm{~mm}<$ Dds $\leq 0.315 \mathrm{~mm}$ )were greater than those blended with «100\% DS » and were lower than that of « $100 \%$ $\mathrm{CS} »$.

The study showed that the incorporation of dune sand with a diameter of less than $0.16 \mathrm{~mm}$ improved the mechanical strength of hardened mortars, Compressive strength increased by $12 \%, 10 \%$ and $2 \%$ respectively, and mortar blended with $30 \% \mathrm{SD}+$ $70 \%$ SC had a better strength than the other mortars, The crystallized particles of dune sand were involved in the formation of the granular skeleton and contributed to the compactness of the cement matrix, which has been confirmed by the previous studies

The results obtained highlight the influence of the sand dune grain diameter on the mechanical properties of the mortars tested.

\section{Acknowledgements}

The author gratefully acknowledges the reviewers for their commitment in reviewing the paper.

\section{References}

1. Z. Demene, L. Azzouz, "Durabilité de mortiers à base de ciments Algériens vis-à-vis du sulfate de magnésium (MgSO4) et effet de sable de dune sur le taux de chute de résistance". Colloque CMEDIMAT.2005

2. R. Chihaoui ,H. Khelafi, "Effets de la pouzzolane naturelle sur la durabilité des mortiers exposés aux attaques sulfatiques", 1 st International Conference on Sustainable Built Environment Infrastructures in Developing Countries ENSET Oran Algeria, 2009.

3. B. Benbacha, K. Elhadj, "Proprieties of selfcompacting mortar made with various types of sand". Cement and concrete composite, Vol. 34, No.10, 2012, pp 1167-1173.

4. N//C Belaribi, M. Semsa, "Influence de la pouzzolane de Beni saf sur les caractéristiques mécaniques des bétons", Canadian journal of civil engineering, Vol. 30, No3, 2003 , pp 580- 584.

5. M. Ashraf M, A. Naeem Khan, A. Qasair, "Physico-chemical, morphological and thermal analysis for the combined pozzolanic activities of minerals additives, Construction and Building Materials, Vol.23, No.6, 2009, pp. 2207- 2213.

6. M. Behim, M. Cyr, "Physical and chemical effects of El-Hadjar slag used as an additive in cementbased materials", European Journal of Environmental and Civil Engineering, Vol.15, No.10, 2011, pp1413-1432.

7. M. Khouadjia., B. Mezghich, "Experimental evaluation of workability and compressive strength of concrete with several local sand and mineral additions", Construction and Building Materials Vol. 98, pp, 2015, 194- 203. 